\title{
Structural Description of Powder Metallurgy Prepared Materials
}

\author{
Alena Michalcová ${ }^{1}$, Dalibor Vojtěch ${ }^{1}$, Tomáš František Kubatík ${ }^{2}$, Pavel Novák ${ }^{1}$, Petr Dvořák \\ ${ }^{1}$ Department of Metals and Corrosion Engineering, Institute of Chemical Technology in Prague, Technická 5, 16628 \\ Prag 6. Czech Republic. E-mail: michalca@vscht.cz, vojtechd@vscht.cz, panovak@vscht.cz, dvorakp@vscht.cz \\ ${ }^{2}$ Institute of Plasma Physics AS CR, v. v. i., Za Slovankou 1782/3, 18200 Prague 8. Czech Republic. E-mail: \\ kubatik@ipp.cas.cz
}

The compaction of powder metals and alloys is very difficult field due to preserving of unique properties of initial materials. One of few possible method of succesful compaction is plasma sintering. To describe detailed structure os powder metallurgy materials, it is necesary to use advanced microscopy methods such as SEM and TEM. In this study, the structure of $\mathrm{NiAl}$ intermetallic compaoud is described. The material was at first produce by reactive sintering from pure elements. Subsequently, the NiAl porous master alloy was milled and compacted by spark plasma sintering (SPS) technique.The particle size of NiAl powder was compareable to the grain size of compact material, which exhibited low porosity. It was proven that the interconnection on NiAl particles is performed by thin layer of nanocrystalline oxides.

Keywords: SPS, intermetallics, powder metallurgy

\section{Acknowledgement}

This research was financially supported by Czech Science Foundation, project No. P108/12/G043.

\section{References}

[1] TINGAUD, D., STUPPFLER, L., PARIS, S., VREL, D., BERNARD, F., PENOT, C., NARDOU, F. (2007). TimeResolved X-ray Diffraction Study of SHS-produced NiAl and NiAl-ZrO2 Composites. International Journal of Self-Propagating High-Temperature Synthesis, Vol. 16, No. 1, pp. 12-17. Springer. Germany.

[2] NOVAK, P., MiCHAlCOVÁ, A., MAREK. I., VODĚROVÁ, M., VOJTĚCH, D. (2012). Possibilities of the observation of chemical reactions during the preparation of intermetallics by reactive sintering. In: Manufacturing Technology, Vol. 12, No. 13, pp. 197-201. Faculty of Production Technology and Management. CR.

[3] ŠVEC M., VODIČKOVÁ, V., HANUS, P. (2012) The effect of heat treatment on the structure of Nb and C doped Fe3Al iron aluminides. . In: Manufacturing Technology, Vol. 12, No. 13, pp. 254-259. Faculty of Production Technology and Management. CR.

[4] ŠVEC M., HANUS, P., VODIČKOVÁ, V. (2013). Coefficient Thermal Expansion of Fe 3Al and FeAl - type iron aluminides. In: Manufacturing Technology, Vol. 13, No. 3, pp. 399-404. Faculty of Production Technology and Management. CR.

[5] EDALATI, K., TOH, S., WATANABE, M., HORITA, Z. (2012). In situ production of bulk intermetallic-based nanocomposites and nanostructured intermetallics by high-pressure torsion. In: Scripta Materialia, Vol. 66, pp. 386-389. Elsevier. US.

[6] NOVÁK, P., ŠOTKA, D., NOVÁK, M., MICHALCOVÁ, A., ŠERÁK, J., VOJTĚCH, D. (2011). Production of NiAl-matrix composites by reactive sintering. In: Powder Metallurgy, Vol. 54, No. 3, pp. 308-313. Maney. UK.

[7] TOKITA, M. (2013). Spark Plasma Sintering (SPS) Method, Systems, and Applications. Handbook of Advanced Ceramics, pp 1149-1177, 2nd ed.; Academic Press: Oxford.

[8] MUNIR, Z. A., ANSELMI-TAMBURINI, U., OHYANAGI, M. (2006). The effect of electric field and pressure on the synthesis and consolidation of materials: A review of the spark plasma sintering method.In: Journal of Materials Science, Vol. 41, No. 3, pp. 763-777. Springer. Germany. 